2

I N S AN

\title{
Apakah Prokrastinator Sejahtera Psikologisnya? Studi Pada Dosen Universitas X di Malang
}

THOYYIBATUS SARIRAH ${ }^{1 *}$

[1] Program Studi Psikologi, Fakultas Ilmu Sosial dan Ilmu Politik, Universitas Brawijaya

\begin{abstract}
ABSTRAK
Tujuan dari penelitian ini adalah untuk mengetahui peranan prokrastinasi dengan kesejahteraan psikologi pada dosen di Universitas X Malang. Responden yang digunakan berjumlah 84 Dosen dengan mengggunakan teknik convenience sampling. Instrumen yang digunakan dalam penelitian ini adalah Uni Procrastination Scale dan Skala Kesejahteraan Psikologis. Hasil analisis data dengan menggunakan regresi liner sederhana, mendukung hipotesis penelitian, yaitu terdapat korelasi antara prokrastinasi dengan kesejahteraan psikologis dengan koefisien korelasi .561 $(\mathrm{p}<.05)$ dan memiliki sumbangan relatif sebesar $31.5 \%$. Penelitian selanjutnya dapat diarahkan untuk menekankan tentang perbedaan individual maupun kelompok dalam kaitannya dengan prokrastinasi dan kesejahteraan psikologis.
\end{abstract}

Kata kunci: prokrastinasi, kesejahteraan psikologis, dosen.

\section{ABSTRACT}

This research aimed to investigate the relation between procrastination with psychological well-being among lectures of X University in Malang. Research participants were 84 lectures and convenience sampling technique was chosen to determine the sample. The instrument of this research were Uni Procrastination Scale and Psychological Well-Being Scale. Results of data analysis by using multipple regression supported research hypothesis that there were moderate correlation between procrastination with psychological well-being with correlation coefficient of .561 $(\mathrm{p}<.05)$ and its relative contribution was reported $31.5 \%$. Further research should be directed to individual and group differences in regards to procrastination and psychological well-being.

Key words: procrastination, psychological well-being, lecturer.

INSAN Jurnal Psikologi dan Kesehatan Mental, 2016, Vol. 1(2), 134-140, doi: 10.20473/JPKM.v1i22016.134-140 Dikirimkan: 25/11/2016 Diterima: 09/12/2016 Diterbitkan: 31/12/2016

Editor: Rizqy Amelia Zein

*Alamat korespondensi: Jalan Veteran Malang, Lowokwaru, Kota Malang, Jawa Timur 65145. Alamat surel: ariexmr@gmail.com.

Naskah ini merupakan naskah dengan akses terbuka dibawah ketentuan the Creative Common Attribution License (http://creativecommons.org/licenses/by/4.0), sehingga penggunaan, distribusi, reproduksi dalam media apapun atas artikel ini tidak dibatasi, selama sumber aslinya disitir dengan baik. 


\section{PEN D A H U L UA N}

Prokrastinasi bukanlah sebuah fenomena yang baru. Hampir semua orang pernah mengalaminya, baik siswa, pekerja, bahkan ibu rumah tangga pernah mengalaminya. Prokrastinasi merupakan masalah yang sangat serius, bahkan di negara Amerika ditemukan lebih 90\% pernah melakukan prokrastinasi (Ellis \& Knaus, 1979 dalam Knaus, 2010). Knaus (2010) mendefinisikan prokrastinasi sebagai kebiasaan yang bermasalah dari menunda aktivitas yang penting dan sesuai dengan waktunya di waktu yang lain. Mayoritas penelitian mengenai prokrastinasi seringkali dikaji pada pelajar atau yang seringkali disebut sebagai prokrastinasi akadedmik. Ozer, Demir dan Ferrari (2009) dengan menggunakan skala Turkish-PASS mereka menemukan bahwa dari 784 pelajar sebagian besar melakukan prokrastinasi terutama pada belajar untuk persiapan ujian, menulis makalah, serta mengulang pelajaran. Pada penelitian ini memfokuskan kepada prokrastinasi yang dialami oleh dosen.

Seorang dosen memiliki tugas dan kewajiban tidak hanya mengajar dan mendidik mahasiswa, akan tetapi ia juga memiliki tugas-tugas yang lain seperti melakukan penelitian, pengabdian, bimbingan skripsi dan lain sebagainya. Dengan kompleksitas tugas yang dialaminya tidak menuntut kemungkinan ia akan menjadi bosan, jenuh, capek, dan lain sebagainya hingga akhirnya mengarah kepada prokrastinasi. Schraw, Wadkins dan Olafson (2007) menyatakan bahwa jika individu dihadapkan dengan tugas yang membosankan, sulit atau tidak menyenangkan akan menyebabkan ia untuk melakukan prokrastinasi.

Penelitian Hammer dan Ferrari (2002) mencoba membandingkan prokrastinasi yang terjadi pada blue-collar workers dan white-collar workers. Mereka menemukan bahwa blue-collar workers (pekerjaan yang tidak membutuhkan keterampilan) dan white-collar workers (profesional and semiprofesional). Hasilnya ditemukan bahwa white collar workers secara signifikan melakukan prokrastinai dibandingkan denganblue-collar workers. Hal ini memperkuat asumsi penulis bahwa Dosen yang termasuk ke dalam golongan white-collar workers, kemungkinan besar melakukan prokrastinasi.

Untuk membedakan antara prokrastinator dan non-prokrastinator, Ferrari dan Diaz-Morales (2007) menemukan bahwa progkrastinator lebih night person atau seringkali melakukan kegiatan di malam hari, sedangkan non-prokrastinator melakukan kegiatan pada siang hari. Hal ini disebabkan prokrastinator lebih menikmati atau termotivasi mengerjakan tugas pada malam hari sebelum tenggat waktu. Prokrastinator memiliki kecenderungan merasakan waktu secara subjektif, bukan secara objektif, sehingga mereka tidak bisa mengantisipasi jika mengalami kesulitan dalam mengerjakan tugas sebelum tenggat waktu, tidak bisa memprediksikan berapa banyak waktu yang dibutuhkan dalam mengerjakan tugas tersebut (Burka \& Yuen, 2008). Dengan sense of time yang cenderung subjektif tersebut mengakibatkan mereka mengalami permasalahan tidak hanya berkaitan dalam pengerjaan tugas saja, akan tetapi aspek-aspek lain seperti berhubungan dengan orang lain, serta tanggung jawab lainnya mengalami hambatan.

Penulis mengasumsikan dosen yang melakukan prokrastinasi akan mengalami hambatan di berbagai aspek, seperti dalam mempersiapkan materi perkuliahan, memberikan umpan balik kepada mahasiswa yang terkait dengan proses pembelajaran, melakukan bimbingan, dan lain sebagainya yang dapat menganggu kelancaran untuk menyelesaikan tugas yang diembannya.

Dengan terhambatnya dalam mengerjakan tugas, dan aspek-aspek lainnya, hal ini dapat mengakibatkan permasalahan psikologis yang akan dialaminya. Pychyl, Coplan dan Reid (2002) menemukan bahwa prokrastinator mengaku mengalami masalah emosional, seperti cemas, takut gagal, rendahnya harga diri, frustasi, dan rendahnya perasaan bersalah. Permasalaan emosi yang dialami oleh prokrastinator bisa dengan cara ia menghadapi kehidupan secara positif. Salah satunya bisa dikaji melalu kesejahteraan diri subyek.

INSAN Jurnal Psikologi dan Kesehatan Mental

2016, Vol. 1(2), 134-140

doi: 10.20473/JPKM.v1i22016.125-131 
Deci dan Ryan (2008 dalam Winefield, dkk. 2012) mendefinisikan kesejahteraan psikologis atau psychological well-being sebagai kombinasi dari afek yang positif, seperti kebahagiaan dan keberfungsian hidup yang optimal dalam kehidupan individu dan sosial. Winefield, dkk. (2012) menemukan dalam penelitiannya bahwasannya seseorang yang memiliki kesejahteraan psikologis yang positif cenderung memiliki tekanan psikologis yang rendah, begitu juga sebaliknya seseorang yang memiliki kesejahteraan psikologis yang rendah ia cenderung mengalami tekanan psikologis yang tinggi.. Lebih lanjut, dari penelitian ini juga menemukan bahwa individu yang memiliki satu anak atau lebih, bercerai atau ditinggal mati oleh pasangan, tidak memilik kualifikasi pendidikan yang memadai serta individu yang pensiun cenderung memiliki bahwa kesejahteraan psikologis yang rendah dan tekanan psikologis yang tinggi.

Konsep kesejahteraan psikologis dipelopori Ryff (1989). Individu yang memiliki kesejahteraan psikologis yang tinggi akan merasa puas dengan kehidupannya, stabil emosinya, mampu melewati pengalaman yang kurang menyenangkan yang dihasillkan oleh kondisi emosi yang negatif dan lain sebagainya. Kesejahteraan psikologis yang dimiliki individu akan mempengaruhi persepsi subyektif dirinya atas segalam proses kehidupan yang dialaminya. Rathi dan Rastogi (2007) menemukan bahwa seseorang yang menganggap hidupnya bermakna serta memiliki tujuan cenderung memiliki bahwa kesejahteraan psikologis yang baik.

Begitu pula pada diri Dosen di mana ia memiliki tugas tidak hanya mendidik mahasiswa, akan tetapi mereka juga memiliki kompleksitas tugas yang lain, seperti melakukan penelitian, dan pengabdian kepada masyarakat. Dengan tugas yang kompleks serta upaya untuk menjalankan komitmen terhadap tugas tersebut, maka penulis mengasumsikan hal tersebut akan berkaitan dengan bahwa kesejahteraan psikologis yang dimilikinya. Penelitian Babajide dan Akintayo (2011)) menemukan bahwa terdapat hubungan yang positif antara tekanan dalam pekerjaan dengan kesejahteraan psikologis, terutama yang berkaitan dengan perilakunya, seperti kepuasan dalam pekerjaan, komitmen terhadap pekerjaan dan kerelaan untuk dikontrol oleh organisasi. Jadi bisa diasumsikan bahwa jika dosen menganggap tugas yang dimilikinya merupakan sesuatu yang membuatnya tertekan, stress, serta pikiran negatif lainnya akan mengakibatkan ia memiliki kesejahteraan psikologis yang rendah. Sebaliknya, jika ia menganggap tugas yang diembannya adalah sebuah tanggung jawab, sesuatu yang menantang, serta menikmatinya maka ia memiliki kecenderungan untuk memiliki kesejahteraan psikologis yang tinggi.

Riset sebelumnya menemukan bahwa kesejahteraan psikologis berhubungan dengan perilaku prososial. Individu yang memiliki kesejahteraan psikologis yang tinggi cenderung memiliki perilaku prososial yang tinggi. Sebaliknya individu yang memiliki kesejahteraan psikologis yang rendah cenderung memiliki perilaku prososial yang rendah (Kumar, 2014). Dengan melihat begitu pentingnya seorang Dosen memiliki kesejahteraan psikologis, hal tersebut tentunya dapat berhubungan dengan prokrastinasi, maka dalam penelitian ini penulis mencoba mengkaji peranan kesejahteraan psikologis terhadap prokrastinasi.

\section{Kesejahteraan Psikologis}

Ryff (1989) merupakan tokoh yang memprakarsai konsep kesejateraan psikologis. Terdapat lima dimensi yang dikemukakan oleh Ryff (1989), yaitu kesejahteraan psikologis antara lain: penerimaan diri (self-acceptance), penguasaan terhadap lingkungan (enviromental mastery), tujuan hidup (purpose in life), hubungan positif dengan orang lain (positive relations with others), pertumbuhan pribadi (personal growth) dan otonomi (autonomy). Ryff (1989 dalam Ryff \& Keyes, 1995) mengatakan bahwa dimensi-dimensi tersebut merupakan aspek yang paling menentukan konsep kesejahteraan 
psikologis. Jadi dapat dikatakan bahwa individu yang memiliki kesejahterhaan psikologis yang tinggi adalah individu yang memiliki nilai yang tinggi pada aspek-aspek tersebut.

\section{Prokrastinasi}

Knaus (2010) menyatakan bahwa kata prokrastinasi berasal dari bahasa Latin pro (forward) dan crastinus (belonging tomorrow) yang memiliki arti menunda sesuatu ke waktu yang lain. Pada definisi ini bisa dikatakan bahwa seseorang disebut sebagai prokrastinator (orang yang melakukan prokrastinasi) jika ia menunda pengerjaan sesuatu ke waktu yang lain, bukan di waktu yang sudah direncanakan, atau tidak sesuai dengan batas waktunya. Menurut Lay (1986), prokrastinator memiliki masalah dalam melakukan sesuatu tepat waktu, karena mereka takut mengalami kegagalan. Selain itu, prokrastinator memiliki ciri-ciri kebutuhan untuk berprestasi yang rendah, memilki perasaan tidak mampu, serta memiliki harga diri yang rendah. Hipotesis dalam penelitian ini adalah terdapat pengaruh kesejahteraan psikologis terhadap prokrastinasi pada dosen di Universitas X Malang.

\section{E T O D E}

\section{Partisipan}

Partisipan dalam penelitian ini adalah 100 Dosen di Universitas X malang. Teknik sampling yang digunakan adalah dengan menggunakan convenience sampling, yaitu siapa saja subyek yang ditemui oleh penulis yang sesuai dengan kriteria yang telah ditentukan sebelumnya.

\section{Pengukuran}

Prokrastinasi. Instrumen penelitian yang digunakan adalah Uni Procrastination Scale (Setiawan, 2010). UPS merupakan pengembangan dari General Procrastination Scale (Lay, 1986) yang sudah diterjemahkan dan sesuai dengan situasi dan kondisi di Indonesia. UPS terdiri dari 5 aitem. Respon jawaban terdiri dari empat alternatif pernyataan yang berkisar dari Sangat Setuju (SS), Setuju (S), Tidak Setuju (TS) dan Sangat Tidak Setuju (STS) yang mengacu pada skala Likert. Terdapat dua bentuk pernyataan dalam penelitian ini, yaitu favourable dan unfavourable. Reliabilitas skala dalam penelitian adalah .724.

Kesejahteraan Psikologis. Kesejahteraan Psikologis menggunakan skala dari Ryff (1989) yang telah diadaptasi dan diterjemahkan ke dalam bahasa Indonesia oleh Rachmayani dan Ramdhani (2014). Skala ini terdiri dari 29 aitem yang diskor dengan menggunakan skala Likert serta terdiri dari jawaban favourable dan unfavourable. Reliablitas dalam penelitian ini adalah .858.

\section{Analisis data}

Analisis data yang digunakan dalam penelitian ini dengan menggunakan teknik regresi linier sederhana yang tujuaannya untuk mengetahui pengaruh dari variabel $\mathrm{X}$ yang dalam penelitian ini adalah kesejahteraan psikologis terhadap variabel terikat, yaitu prokrastinasi. 


\section{HAS IL PENELIT I A N}

\section{Uji Hipotesis}

Berdasarkan hasil uji hipotesis ditemukan bahwa nilai $\mathrm{p}=.000(\mathrm{p}<.05)$ yang berarti hipotesis alternatif diterima, yaitu terdapat peranan prokrastinasi terhadap kesejahteraan psikologis dengan nilai $\mathrm{t}=6.141$, yang berarti terdapat hubungan positif antara prokrastinasi dengan kesejahteraan psikologis. Adapun sumbangan relatif dalam penelitian ini sebesar $31.5 \%$.

\section{Uji korelasi berdasarkan dimensi kesejateraan psikologis dengan prokrastinasi}

Tabel 1. Korelasi Dimensi Kesejahteraan Psikologis dengan Prokrastinasi

\begin{tabular}{lcc}
\hline \multicolumn{1}{c}{ Variabel } & Prokrastinasi & Nilai p \\
\hline Kesejahteraan psikologis & .561 & .000 \\
Otonomi & -.394 & .000 \\
Penguasaan Terhadap Lingkungan & -.376 & .000 \\
Pertumbuhan Pribadi & -.439 & .000 \\
Relasi Positif dengan Orang Lain & -.422 & .000 \\
Tujuan Hidup & -.542 & .000 \\
Penerimaan Diri & -.624 & .000 \\
\hline
\end{tabular}

Berdasarkan tabel di atas dapat ditemukan bahwa kesejahteraan psikologis berhubungan secara signifikan dengan prokrastinasi. Akan tetapi, jika dillihat berdasarkan semua dimensi kesejahteraan psikologis ditemukan berhubungan negatif secara signifikan dengan prokrastinasi. Dimensi yang tertinggi yang berhubungan dengan prokrastinasi adalah penerimaan diri.

\section{I S K U S I}

Berdasarkan hasil penelitian ini menemukan bahwa hipotesis diterima, yaitu terdapat pengaruh prokrastinasi terhadap kesejahteraan psikologis individu. hasil penelitian tersebut diperkuat oleh penelitian Pychyl, dkk. (2002) di mana mereka menemukan bahwa seorang yang prokrastinasi cenderung mengalami masalah emosional, seperti cemas, takut gagal, dan lain sebagainya atau bisa dikatakan bahwa individu tersebut belum bisa memandang dirinya secara positif dan hal tersebut berkaitan dengan kesejahteraan psikologisnya. Jika individu tersebut mengaku mengalami tekanan dalam pekerjaannya, ia akan cenderung mengalami kesejahteraan psikologis yang rendah, sebaliknya jika individu mengaku tidak mengalami tekanan dalam pekerjaannya, ia cenderung mengalami kesejahteraan psikologis yang. Hal ini dikarenakan kesejahteraan psikologis berhubungan dengan tekanan dalam pekerjaan (Babajide \& Akintayo, 2011). menemukan bahwa terdapat hubungan yang positif antara tekanan dalam pekerjaan dengan kesejahteraan psikologis, terutama yang berkaitan dengan perilakunya, seperti kepuasan dalam pekerjaan, komitmen terhadap pekerjaan dan kerelaan untuk dikontrol oleh organisasi.

Berdasarkan uji korelasi ditemukan bahwa terdapat hubungan positif prokrastinasi dengan kesejahteraan psikologis. Akan tetapi jika dilihat berdasarkan dimensi-dimensi kesejahteraan psikologis hubungannya adalah negatif. Hal ini berarti semakian tinggi skor partisipan pada dimensidimensi dalam kesejahteraan psikologis, maka semakin rendah kecenderungan prokrastinasi. Hasil penelitian ini sesuai dengan penelitian sebelumnya yang menemukan bahwa kesejahteraan psikologis berhubungan dengan prokrastinasi, dimana otonomi berhubungan positif dengan "prokrastinasi aktif", yaitu individu yang memiliki kemampuan dalam mengerjakan tugas atau pekerjaannya, akan tetapi ia menunda mengerjakannya, dan tujuan hidup berhubungan negatif dengan "prokrastinasi INSAN Jurnal Psikologi dan Kesehatan Mental 2016, Vol. 1(2), 134-140

doi: 10.20473/JPKM.v1i22016.125-131

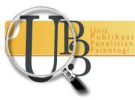


pasif", yaitu individu yang merasa tidak memiliki kemampuan dalam mengerjakan tugas atau pekerjaannya, sehingga ia menunda waktu dalam mengerjakannya (Habelrih \& Hicks, 2015).

\section{PUSTAKA ACUAN}

Babajide, E.O. \& Akintayo, I. (2011). Being and workers' behaviour in manufacturing industries in South-West Nigeria. International Journal of Management and Innovation, 3(1), 32-42.

Burka, J. B. \& Yuen, L. M. (2008). Procrastination: Why you do it, what to do about it now. Cambridge: Life Long.

Ferrari, J. R., \& Díaz-Morales, J. F. (2007). Procrastination: Different time orientations reflect different motives. Journal of Research in Personality, 41(3), 707-714.

Habelrih, E. A., \& Hicks, R. E. (2015). Psychological well-being and its relationships with active and passive procrastination. International Journal of Psychological Studies, 7(3), 25.

Hammer, C. A., \& Ferrari, J. R. (2002). Differential incidence of procrastination between blue and white-collar workers. Current Psychology, 21(4), 333-338.

Knaus, W. (2010). End procrastination now! Get it done with a proven psychological approach. New York: McGraw Hill

Kumar, R. (2014). Psychological well-being among adolescents: Role of prosocial behaviour. Indian Journal of Health and Wellbeing, 5(3), 368.

Lay, C. H. (1986). At last, my research article on procrastination. Journal of research in personality, 20(4), 474-495.

Özer, B. U., Demir, A., \& Ferrari, J. R. (2009). Exploring academic procrastination among Turkish students: Possible gender differences in prevalence and reasons. The Journal of social psychology, 149(2), 241-257.

Pychyl, T. A., Coplan, R. J., \& Reid, P. A. (2002). Parenting and procrastination: gender differences in the relations between procrastination, parenting style and self-worth in early adolescence. Personality and Individual Differences, 33(2), 271-285.

Rachmayani, D \& Ramdhani, N. (2014). Literasi digital sebagai mediator hubungan antara ciri kepribadian extraversion, neuroticism, dan opennes to experience dengan psychological well-being pada remaja pengguna teknologi. Tesis tidak dipublikasikan. Universitas Gajah Mada. Yogyakarta.

Rathi, N., \& Rastogi, R. (2007). Meaning in life and psychological well-being in pre-adolescents and adolescents. Journal of the Indian Academy of Applied Psychology, 33(1), 31-38.

Ryff, C. D. (1989). Happiness is everything, or is it? Explorations on the meaning of psychological wellbeing. Journal of personality and social psychology, 57(6), 1069.

Ryff, C. D., \& Keyes, C. L. M. (1995). The structure of psychological well-being revisited. Journal of personality and social psychology, 69(4), 719.

Schraw, G., Wadkins, T., \& Olafson, L. (2007). Doing the things we do: A grounded theory of academic procrastination. Journal of Educational psychology, 99(1), 12.

Setiawan, I (2013). If i am sure to do that now, ...” Penyusunan uni procrastination scale (UPS). Jurnal Ilmiah Mahasiswa Universitas Surabaya. 2(1).

INSAN Jurnal Psikologi dan Kesehatan Mental

2016, Vol. 1(2), 134-140

doi: 10.20473/JPKM.v1i22016.125-131 
Winefield, H. R. Gill, T. K., Taylor, A. W. \& Pilkington, R. M. (2012). Psychological well-being and psychological distress; Is it necessary to measure both? Psychology of Well-Being: Theory, Research, and Practice, 23. Diakses dari http://www.psywb.com/conten/conten/2/1/3. 